This item was submitted to Loughborough's Research Repository by the author.

Items in Figshare are protected by copyright, with all rights reserved, unless otherwise indicated.

\title{
Making worlds, making subjects: contemporary art and the affective dimension of global ethics
}

PLEASE CITE THE PUBLISHED VERSION

http://dx.doi.org/10.1080/21500894.2011.602716

\section{PUBLISHER}

(C) Taylor \& Francis (Routledge)

\section{VERSION}

AM (Accepted Manuscript)

\section{LICENCE}

CC BY-NC-ND 4.0

\section{REPOSITORY RECORD}

Meskimmon, Marsha. 2019. "Making Worlds, Making Subjects: Contemporary Art and the Affective Dimension of Global Ethics". figshare. https://hdl.handle.net/2134/9532. 
This item was submitted to Loughborough's Institutional Repository (https://dspace.lboro.ac.uk/) by the author and is made available under the following Creative Commons Licence conditions.

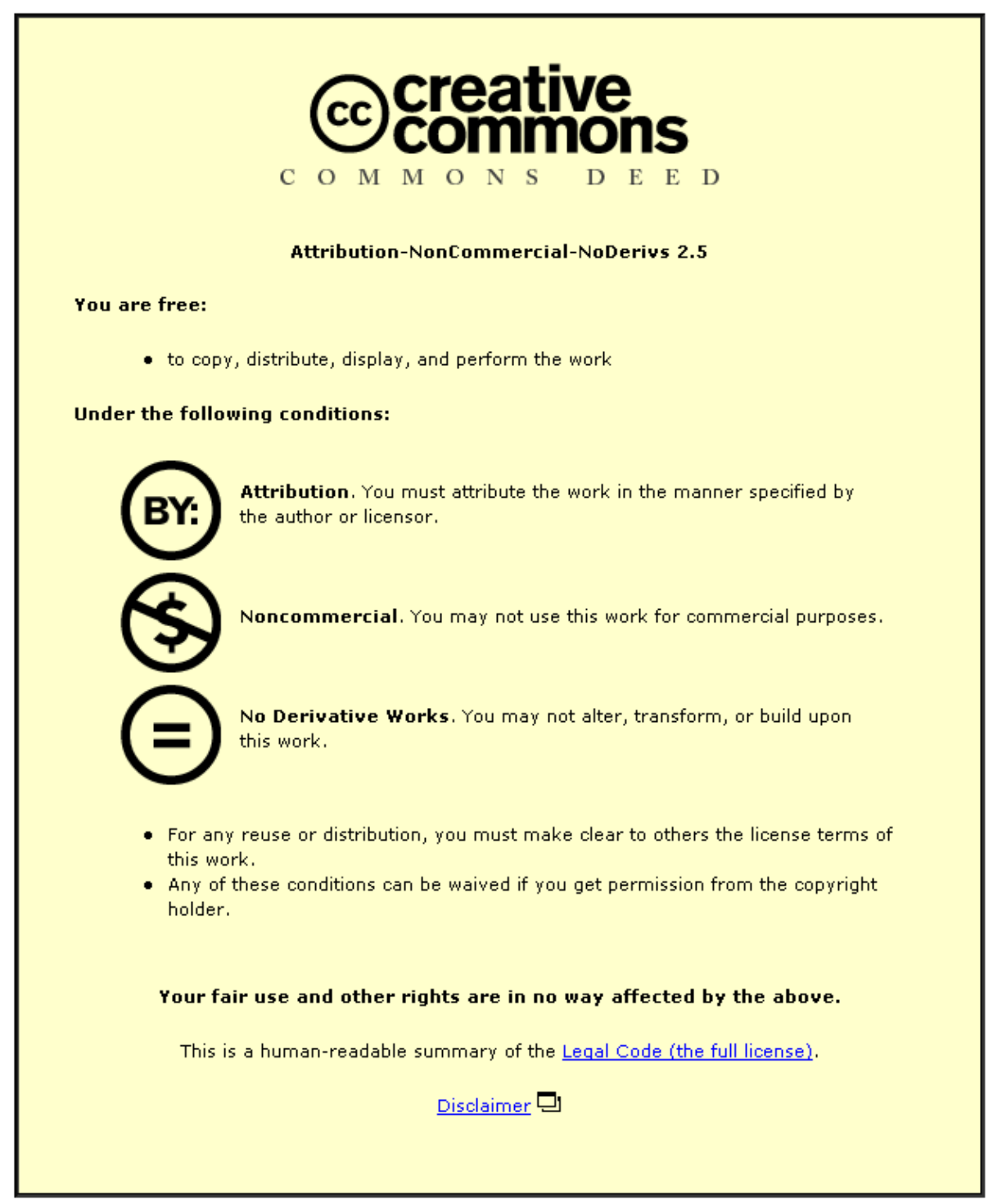

For the full text of this licence, please go to: http://creativecommons.org/licenses/by-nc-nd/2.5/ 
Making Worlds, Making Subjects:

Contemporary Art and the Affective Dimension of Global Ethics Marsha Meskimmon 
In his article for the present issue of World Art, Terry Smith offers a thoughtful account of the global impact of contemporary art that neither presumes the category itself ('contemporary art') nor neglects the spatio-temporal dynamics of its worldly engagement. Rather, Smith's text focuses on what he calls 'currents of world-making' that enable his enquiry to test the limits of what we understand to be 'contemporary' practice whilst acknowledging the agency of art in the production of 'worlds', themselves mutable, complex and multi-layered.

Smith is not afraid to say that contemporary art is 'essentially, definitively and distinctively worldly.' [3, italics in original] The effect of this position is both to refute the notion of art as a transcendent aesthetic category beyond the material reach of history and to argue strongly for its embeddedness within the specific spatio-temporal location(s) of its production and consumption. As Smith contends, art is 'from the whole world' and may well become 'for the world ... the world as it is now, and as it might be.' [3, italics in original] It is the latter element of that claim ('for... the world... as it might be'), when extended to consider the ethical dimensions of 'contemporary world art', that I find especially compelling.

Clearly, what constitutes 'the world' (and its art) is pivotal to Smith's article, to any consideration of art's ethical agency and, indeed, to this journal. In the first issue of World Art, the editors offered a series of provocative statements on precisely this point, referring to a 'network of diverse intellectual, artistic and curatorial activities centred on human creativity', an 'unfolding matrix of practice-based networks' and to the 'world-wide field of writing, making and sensing art.' (Editorial 1:1 2010, 1-7) The emphasis placed in these statements upon networks and overlapping fields of activity suggests that 'world art' might be understood as in the making; arguably, this opens closed intellectual and disciplinary categories to new forms of enquiry and, I would suggest, to the significant question of difference.

The account of 'the world' in Smith's text accords with the open-ended matrices proposed by the editors of World Art, and, crucially, is neither premised upon a generalised, a-historical model nor harnessed to the radical relativism that too commonly undermines arguments around process and multiplicity. Smith's account of 'the world' is developed through the worldliness of contemporary art, by which he means an art that has emerged in distinct currents 'since the later decades of the twentieth century' [8] and is embedded within a particular experience of 'the world' as meaning 'a number of different things. But not an infinite number, nor even a plurality; rather, a specific cluster of different things.' [5]

This cluster brings Smith to time. The three currents of world-making that, he argues, distinguish contemporary art are precisely locatable within the etymology of the 'contemporary'; they are 'with time'. The first current consists of what Smith calls 'official, institutionalized Contemporary Art', [8] an art typified by 'Remodernism' and 'RetroSensationalism' [9]. Smith's terms might seem coded, but are, in fact, powerfully descriptive and very effective in defining this current - it is the mainstream work that feeds every large- 
scale, metropolitan museum of contemporary art in the world today. Smith delineates his second current as 'the transnational turn' [10], an art driven by a post- and/or anti-colonial aspiration for a cosmopolitan world, fostered by dialogues between the local and the global that take place through the international circuits of the art world (typified by numerous bi- and triennials). The third current in Smith's model is more 'personal, small-scale and modest' [12]; it is the result of the work of many individual artists and loose collectives who operate at the interstices of new and old media to explore the possibility of sustainable communities and 'close-valued placemaking' [14].

Smith's commitment to locating the multiple worlds-in-the-making that constitute the field of contemporary art distinguishes his account from much of the current literature circulating through the global art market that attempts to make the work palatable, and thus, easy to consume. (Cf. Smith 2009; 2011) Smith, instead, maintains a politics around the production and consumption of meaning in contemporary art that is laudable and I found the invitation to respond to his article here both exciting and challenging.

As I suggested earlier in this piece, it is the extension of Smith's argument concerning the worldliness of contemporary art (in and through time) toward an understanding of the ethical potential of contemporary practice that I would like to explore. Smith's astute argument recognises the political dimension of contemporary art's space- and placemaking potential through distinctive, yet coeval, temporal currents. Though the three 'currents' are framed within the article as simply concurrent, I would suggest that Smith's definition of the currents can be seen to set up a more complex, materialist account of the historical processes of contemporary practice by means of what might be called a contemporal dialectic. That is, the first, official, current stands in his account in the position of a thesis, the second current where we have 'for decades' had work that 'matches the strongest art of the first current' [10] - an antithesis, and, the third current, defined by 'younger artists... draw[ing] on elements of the first two tendencies' [12], produces a synthesis. Significantly, that synthesis points toward the future.

Temporally, then, Smith's account is not simply a diachronic progress narrative, nor is it a straightforward case of synchronicity; the currents of the contemporal dialectic described here produce a 'thickened' present [4] that admits of difference and diversity. And, if the 'contemporaneity' of art is profoundly embedded within the world, then it can have a significant role to play in imagining the world otherwise - in becoming 'for the world' not just as it is, but 'as it might be'. These insights imply that art might elicit an ethical agency, but, as I have argued elsewhere, this necessitates us thinking through art beyond even a 'thickened' present toward the production of a non-teleological future. (Meskimmon 2003; 2010)

Engaging productively with the time of contemporary art in this sense does more than describe its embeddedness within the world as it exists now, it offers the potential to make the world otherwise in future. Smith alludes to this in several places, specifically in relation to the third current or synthesis, where he writes of 'imagin(ing) possible worlds' [13], as a 
'hope-filled enterprise' [15], but his central concerns are not with the ethical agency of contemporary art. I should like, in the spirit of the present dialogue with Smith's text, to develop some ideas around this 'hope-filled' enterprise in what follows.

I am interested in arguments concerning the temporal dimension of contemporary art for a number of reasons, not least because I am committed to thinking through the question of art's agency in world-making, which I would suggest finds its greatest resonance in the interconnection between ethics and aesthetics. That is, the ethical agency of art does not merely reside within a teleological model of world-making where the present always delivers the image of itself as the future, but rather within the registers of imagination, affect and the logic of the gift - where the future can be made anew and opened to difference. Thus the future, while absolutely intertwined with the material legacy of the past and present, is not predetermined by it; the direction of the future cannot be compelled or contained by a reflection of the past or, as Moira Gatens put it:

It's not as if one says 'here is the future, a blueprint', but rather by questioning past practices and by revaluing present practices, one causes a shift or a tremor in the web. (Maras and Rizzo 1995, 65)

Moreover, while art is a highly contested and political terrain, it does not command legislative force, nor can it compel subjects to act in a monolithic or unified manner. Thus I do not equate the potential of art to make worlds with a political imperative of the contractual sort; art compels, but it does so at the level of the subject and through the power of the cultural imaginary. In this sense, I would suggest that art is absolutely embedded within the geopolitical conditions of its time, that it is, as Smith says, worldly, but that its world-making agency is ethical. More strongly, I would argue that as a mode of ethical agency, art's potential is particular, not general or overarching.

Art is capable of mobilising sensory forms of engagement and tapping into affective economies of meaning that can enable subjects to imagine difference, to encounter diverse others and to respond to them. Arguably, art can develop our 'response-ability' in such a way as to (re)connect us with (very different) others in the world - it can interpellate subjects as embodied and materially located or 'enworlded'. And, as Kelly Oliver has argued eloquently, '(t)here is a direct connection between the response-ability of subjectivity and ethical and political responsibility.' (Oliver 2001, 19)

Connections made through art between subjective response-ability and social, political and ethical responsibility have important ramifications for thinking subjectivity in and as sociality, as an embedded, phenomenological condition of becoming a fully-sensory subject.

Significantly, this reconception of the subject challenges the idea that subjects individuate, or come into being as 'singular' selves, through a process of separation and rejection of other(nes)s. Differentiation need not be a brutal isolation of the self from the other, but a mutual recognition of difference that includes generosity and intercorporeal interdependence. 
The subject thus interpellated is not founded in originary violence or a rejection of a generalised 'other', but in interconnection with particular others in the world, with whom we share pressing concerns.

The development of the fully social, fully sensory, subject is at the heart of contemporary art's articulation of an ethical address to the political conditions of globalization. Where artworks can offer us the imaginative space to encounter difference, they may also enable us to mobilize the nexus between response-ability and responsibility, such that a change that is effected at the level of the subject has the potential to transform social and political life in material ways.

The transformative potential of contemporary art is not assured, not able to be contracted, frequently fleeting and quixotic. It engages with imagination at the flashpoint between the cultural imaginary and the imaginative worlds of individuals and moves in the fluid channels of aesthetics and affect. It is profoundly constitutive of subjectivity and culture and yet not fixed; contemporary art's ethical agency partakes of the logic of the gift.

While this is not the place to examine the literature on 'the gift' in detail, it is important that I am clear about my own use of this complex term here. Aware of Jacques Derrida's critique of the gift (Derrida 1992), I nonetheless maintain the alignment of the gift and generosity with a notion of social interaction beyond contractual reciprocity. I follow the work of, for example, Paul Ricoeur and Rosalyn Diprose in thinking through the notion of the gift as linked to an intersubjective, intercorporeal conception of the subject engendered through generosity and a commitment to the open potential of the future, beyond teleology or the mute reflection of the past. In this way, I connect the logic of the gift, the open-ended future and the responseable subject with the ethical agency of contemporary art as it makes worlds, rather than mirrors them.

Specifically, Ricoeur developed a linguistic construction of the gift as a form of futureoriented, ethical generosity that moves from the logic of exchange/demand ('I give so that you will give'), to an open-ended formulation: 'Give because it has been given you'. (Ricoeur 1996, 36) If Ricoeur's formulation demonstrates the potential of the gift to establish social relations open to transformation and difference in time, Diprose's work on embodiment, ethics and generosity, articulated the transformative power of the gift as '.. being given to others without deliberation in a field of intercorporeality, a being given that constitutes the self as affective and being affected, that constitutes social relations and that which is given in relation.' (Diprose 2002, 5) For Diprose, generosity and the gift predicate both sociality and the self in a relation of mutuality and intimate interconnection. Additionally, her conception of generosity works at the level of affectivity, not, she makes clear, as a kind of personal 'feeling' but as 'the production and transformation of the corporeal self through others. So understood, affectivity is also the domain of politics.' (Diprose 2002, 75)

Placing affectivity at the heart of her conception of intercorporeal subjectivity, Diprose's argument reinforces the significance of aesthetics to ethics. Artworks have the potential to interpellate response-able/responsible subjects and enable the emergence of a generous 
connection with others, without negating the pressing problems of globalization and the iniquitous power relations it produces. However, whilst I am arguing that transformations in subjectivity can occur through the agency of future-oriented generosity, I am not arguing that every work of art is a 'gift' and certainly not that artists 'give us gifts'. That would return us to the co-opted logic of contract and not of generosity - indeed it would make it impossible for any art in a global marketplace to demonstrate ethical agency.

Distinguishing between the economies of the gift and the market is important here, since my argument suggests that contemporary art can signify differently within, and sometimes as a counter to, the global marketplace. Art is thoroughly embedded within global markets and invoking the logic of the gift does not seek to negate that through a misplaced philosophical idealism. Contemporary art is a high-level commodity, frequently traded between key metropolitan centres, circulated through bi- and triennials, and used as a form of "cultural capital' to mark global corporate partnerships. But it is precisely the embeddedness of art within the global marketplace that enables it to engage with pressing political and ethical questions concerning location, power and difference. Contemporary art is worldly, it circulates within the world, within the market economy, but it does not simply exist in bondage to hegemonic structures of meaning, knowledge or subjectivity.

Affective agency has transformative potential, an ability to use the material of the past and present to change the future and engender the new. Indeed, contemporary art's ability to mobilize the gift from within the market provides a much stronger ethical imperative than an idealist formulation of the gift as a 'realm' outside or beyond the conditions of globalization. And, if contemporary art is indeed worldly - from the world and for the world, both as it is and as it might be - then we must be prepared to make the case that it can and does, at some times, and in some places, make worlds that imagine connections and relations between very different others for whom and with whom we are responsible in our shared worlds.

\section{References}

Derrida, Jacques. (1992) Given Time 1: Counterfeit Money University of Chicago Press, Chicago and London

Diprose, Rosalyn. (2002) Corporeal Generosity: On Giving with Nietzsche, Merleau-Ponty and Levinas, SUNY Press, Albany NY

The Editors. (2010) 'Editorial', World Art, 1:1, 1-7

Maras, Steven and Teresa Rizzo. (1995) 'On Becoming: An Interview with Moira Gatens', Southern Review, 28, 53-68 
Meskimmon, Marsha. (2003) Women Making Art: History, Subjectivity, Aesthetics Routledge, London and New York

Meskimmon, Marsha. (2010) Contemporary Art and the Cosmopolitan Imagination Routledge, London and New York

Oliver, Kelly. (2001) Witnessing: Beyond Recognition Minnesota University Press, Minneapolis, MN and London

Ricoeur, Paul. (1996) 'Love and Justice' in Paul Ricoeur: The Hermeneutics of Action, ed. Richard Kearney, Sage, London, Thousand Oaks, New Delhi, 23-39

Smith, Terry. (2009) What is Contemporary Art? University of Chicago Press, Chicago IL 